\title{
OB OSEMDESETLETNICI ZASLUŽNEGA REDNEGA PROF. DR., DR. H. C. MIRKA PAKA
}

Slavljenca dr. Mirka Paka, ki je 12. novembra 2016 dopolnil osemdeset let, širši geografski javnosti verjetno ni potrebno podrobno predstavljati. S svojim pedagoškim, znanstveno-raziskovalnim, strokovnim in društvenim delovanjem se je uveljavil kot eden vodilnih slovenskih urbanih, socialnih in regionalnih geografov. Odlikuje se z izjemno bogato bibliografijo in mednarodno znanstveno-raziskovalno dejavnostjo. Njegov znanstveni opus obsega več kot 150 znanstvenih razprav, predvsem s področja urbane, socialne in regionalne geografije.

Dr. Mirko Pak se je rodil 12. 11. 1936 v Mariboru, kjer je obiskoval II. Gimnazijo. Leta 1961 je diplomiral na Oddelku za geografijo na Filozofski fakulteti v Ljubljani. Leta 1965 je na isti fakulteti doktoriral z disertacijo Družbena geografija Zgornjega Dravskega polja. Od leta 1962 je bil zaposlen kot asistent, od leta 1968 kot docent. Leta 1977 je napredoval v izrednega in leta $1988 \mathrm{v}$ rednega profesorja. Bil je prodekan in dekan Filozofske fakultete ter predstojnik Oddelka za geografijo. Njegovo dolgoletno pedagoško delo je bilo usmerjeno v urbano geografijo in regionalno geografijo Evrope. Še posebno pa se je uveljavil kot predavatelj regionalne geografije območja nekdanje Jugoslavije.

Njegovo znanstveno-raziskovalno delo je izjemno bogato in raznovrstno. Razvil je kompleksen socialnogeografski in regionalnogeografski pristop. Njegovo osnovno raziskovalno področje je urbana geografija. Ukvarja se zlasti s problematiko socialnogeografske in funkcijske zgradbe ter preobrazbe mest. Kot eden prvih slovenskih geografov se je tako lotil problematike socialnogeografske zgradbe in socialno degradiranih območij $\mathrm{v}$ slovenskih mestih. V osemdesetih letih 20. stoletja je svoje raziskave usmeril tudi v področje suburbanizacije in razvoja podeželja pod vplivom mest in urbanizacije. Kasneje se je ukvarjal zlasti z vprašanji funkcijske zgradbe in preobrazbe slovenskih mest. V devetdesetih letih 20. stoletja je podrobno preučeval prostorske učinke gospodarske tranzicije na razvoj in zgradbo slovenskih mest. Še zlasti ga je zanimala preobrazba trgovine in drugih oskrbnih dejavnosti v mestih. Poleg urbane geografije je dr. Mirko Pak stalno razvijal tudi regionalno geografijo. Posebno pozornost je namenil severovzhodni Sloveniji, med drugim je bil vodja raziskovalnega projekta o možnostih regionalnega razvoja Spodnjega Podravja s Prlekijo. Preučeval je tudi problematiko obmejnosti in obmejnih regij, še zlasti na slovensko-hrvaški meji v dolgoletnem sodelovanju s hrvaškimi geografi. Stalno ga je zanimala problematika nerazvitosti in regionalnega razvoja.

Dr. Mirko Pak je prav gotovo eden izmed mednarodno najbolj dejavnih slovenskih geografov. Njegova mednarodna aktivnost se je pričela s študijskimi in raziskovalnimi obiski na številnih univerzah in znanstvenih inštitutih v Evropi. Svoje raziskovalno delo je stalno izpopolnjeval na mednarodnih znanstvenih srečanjih, zlasti z nemškimi in hrvaškimi geografi. Dr. Mirko Pak je tudi član številnih mednarodnih strokovnih in znanstvenih združenj, naj izpostavimo le Komisijo za urbano geografijo pri Mednarodni geografski zvezi in Nemško akademijo za regionalno in prostorsko planiranje ARL. Leta 2003 je bilo v Ljubljani na Oddelku za geografijo v organizaciji dr. Mirka Paka izvedeno izredno 
uspešno zasedanje Komisije za urbano geografijo pri Mednarodni geografski zvezi. Veliko priznanje njegovemu znanstveno-raziskovalnemu delu in mednarodnemu delovanju predstavlja častni doktorat Univerze v Pecsu na Madžarskem, ki mu je bil podeljen marca leta 2001. Častni doktorat je bil dr. Mirku Paku podeljen za njegovo obsežno znanstveno-raziskovalno delo in sodelovanje z madžarskimi geografi. Leta 2005 je prejel tudi naziv zaslužnega profesorja Univerze v Ljubljani.

Slika: Redni prof. dr., dr. h. c. Mirko Pak na otvoritvi razstave ob njegovi osemdesetletnici na Oddelku za geografijo na Filozofski fakulteti v Ljubljani (foto: B. Rogelj).

Vrsto let je prevzemal zahtevne in odgovorne strokovne zadolžitve. Bil je predsednik in podpredsednik Zveze geografskih društev Jugoslavije, predsednik Geografskega društva Slovenije in predsednik Komisije za znanstveno delo pri Zvezi geografskih društev Slovenije. Od leta 1995 je častni član Hrvaškega geografskega društva. Dolga leta je opravljal zahtevno uredniško delo. Bil je glavni urednik Atlasa SRS, namestnik glavnega urednika Atlasa SFRJ in geografski urednik pri Enciklopediji Jugoslavije.

Leta 2003 se je dr. Mirko Pak kot redni profesor upokojil, kar pa še ni pomenilo zaključka njegovega znanstveno-raziskovalnega in strokovnega delovanja. Še naprej se je raziskovalno ukvarjal s problematiko razvoja in zgradbe slovenskih mest ter vprašanji regionalnega razvoja. Udeležuje se geografskih znanstvenih srečanj in družabnih prireditev. Ob njegovi sedemdesetletnici je Oddelek za geografijo v letu 2007 pripravil znanstveno srečanje na temo razvoja slovenskih in evropskih mest. Ob njegovi osemdesetletnici pa je bila na Oddelku za geografijo 21. oktobra 2016 odprta priložnostna razstava, ki prikazuje življenje in delo slavljenca. Poleg tega je predstavljen študentski raziskovalni projekt o procesih suburbanizacije med Ljubljano in Vrhniko. Na ta način smo na Oddelku za geografijo želeli prikazati, da tudi mlajša generacija geografov nadaljuje z raziskovanjem tematik, s katerimi se je ukvarjal dr. Mirko Pak. Ob otvoritvi razstave je bila pripravljena krajša slovesnost, ki se je je udeležilo veliko število sodelavcev, diplomantov, doktorandov in prijateljev našega slavljenca.

Profesorju dr. Mirku Paku iskreno čestitamo. Želimo mu veliko osebnega zadovoljstva v krogu družine, predvsem pa obilo zdravja in dobrega počutja. Prav tako mu želimo, da bi še nadalje ohranil svojo iskrivost in geografsko radovednost.

Dejan Rebernik 